\title{
What do we talk about when we talk about the academisation of journalism?
}

\author{
BY BIRGITTE KJOS FONN
}

\begin{abstract}
Well over a hundred years after the first journalism programmes were established at university level, the so-called academisation of journalism education is still subject to dispute. However, academisation is not one thing but many, and this article is an attempt to distinguish between several features making up the academisation of journalism. The approach is historical, primarily based on documentation from the history of Norway's journalism education, as an understanding of when and how various traits of academisation that today seem to constitute one whole were introduced, can help us distinguish between the different forms. I distinguish between academisation from 'above' and academisation from 'within', and identify two kinds of academisation from above and six kinds of academisation from within. This is leading to a typology of eight different types of academisation of journalism.
\end{abstract}

\section{Introduction}

Lofty theories, advanced expressions that could easily be replaced by everyday language, and teachers who do not know the first thing about real life? Or a necessity for best practice and professionalisation of the trade? Well over a century after the first 
university programme of journalism was established, there is still conflict between the supporters and the opponents of journalism as an academic discipline (Hovden, Nygren and ZilliacusTikkanen 2016; Josephi 2009; Zelizer 2009), and this conflict has not diminished with the current economic media crisis.

Since tertiary-level journalism education originated in the USA around 1900, a tradition of apprenticeships - or, in some cases, independent vocational schools - was supplied by or (most often) transformed into academic educational institutions in many countries. From the 1980s and 1990s onwards, journalism has been accepted around the world as a subject field, although as prominent a country as the UK did not have university-based journalism schools until the end of the twentieth century (Josephi 2009:43, 48). The Scandinavian countries established journalism schools around 1960.

To the extent that journalism programmes around the world are academised, they often belong to the group of professional programmes in the institutional structures of higher education, as opposed to the more disciplinary programmes. The attempt to acquire an academic foundation is a well-known strategy in the process of professionalisation. A semi-profession (Ottosen 2004) such as journalism is no exception. But this merging of what was formerly vocational training with the universities' systems and methods has often been seen as a clash of civilisations - a conflict between the academy and the industry 'that shows few signs of easing', as Beate Josephi puts it (2009:47).

Jens-Christian Smeby and Molly Sutphen (2015:1) describe professional education as a special type of education: 'Students within these programmes are not only expected to acquire a cognitive knowledge base; they also have to learn how to use it to solve practical problems in a responsible way within their occupational field.' In view of the history of most educations of this sort, the description could also be phrased the other way around: the practical problems are the foundation, but it is acknowledged that the students need to have a cognitive knowledge base as well. At the core of the abovementioned conflict, however, is the question of whether these two aspects are compatible or whether the achievement of one will be at the cost of the other. In other words, is academisation good or bad for the trade? ${ }^{1}$ 
This article does not attempt to answer that question, but is rather an attempt to distinguish between many of those different aspects that people of the trade and media academics all talk about when they discuss the academisation of journalism. Without a clear idea of the differences (if not clear-cut demarcation lines) between various kinds of academisation, there is a risk of an unclear and untidy debate.

According to Svein Kyvik (2009, cited in Messel and Smeby 2017:45), academisation is usually understood as involving more research activity on the part of the teachers, more theory as part of the teaching, and more university-like teaching. When studying the processes and ways in which academic thought and practice have been introduced into journalism education in Norway, one finds that the process can be even more diverse and complex.

This article builds predominantly on material from Norway's history of journalism education, but also includes a few references to Sweden. Based on a total of eight different kinds of academisation that I have been able to identify in the Norwegian material, I will develop a typology of academisations of journalism.

I initially discuss academisation from above as opposed to within the academy. This is inspired by a distinction originally made with regard to professionalisation by Charles McClelland (1990, cited in Evetts 2003:298), where professionalisation from 'above' is understood as initiatives from forces external to the practitioners (managers, bureaucrats or even authorities) and 'within' is understood as initiatives taken by the practitioners themselves.

I will in what follows distinguish between two types of academisation from above which depend on whether the initiatives come from (1) political bodies, or (2) other forces external to the practitioners; and then proceed to six different aspects of academisation from within the academy, which I call: (3) academisation surrounding journalism; (4) the integrated academisation of journalism teaching; (5) journalism research through other disciplines; (6) institutionalised journalism studies; (7) reflective journalism studies; and (8) academised practice. 
The different types are not necessarily mutually exclusive. They occur for the first time at different points in the history of journalism education in Norway, but thereafter I generally find them coexisting within the same institutional framework.

\section{Tracing historical roots}

First, a few words about my approach. Tracing historical roots can be a fruitful way of distinguishing between the varying traits of a phenomenon that at first sight seem to be more or less the same. As Kaarle Nordenstreng has put it in an article about whether communications studies should be considered a discipline or a field: 'The true nature of the discipline can be discovered only through a careful examination of its historical evolution and institutional position in each case' (Nordenstreng 2007:215).

History, in other words, can be a valuable tool in trying to understand present-day phenomena. When we know how different features originated we can follow their trajectories all the way to the current state. History can be likened to the building of a stone wall - after the wall is finished, it is still possible to see the different stones and their functions. There is of course no reason why one could not also study different kinds of academisation from a synchronic perspective, but history can enable us to see the nuances in the whole that we take for granted today. As academic journalism has such a short history in many countries, records that show the processes have also often been preserved, and the various historical 'layers' can therefore provide valuable information about the meeting points between the vocational and academic streams.

Most of the knowledge we have of the short history of journalism education stems from the United States, but it is important also to pay attention to other countries' histories. In Scandinavia, both Sweden and Norway have fairly recently conducted research projects on their educational histories. Sweden's 'J-school' history, from the early plans in the 1940s until around 1970, has been thoroughly documented by Elin Gardeström (2011), whereas Norway's history is documented by the author 
of this article, (Fonn 2015), from the 1950s until the turn of the century. For a short overview of educational development in all the Nordic countries, see Hovden et al. 2016.

The development in Norway, and subsequently the elements in my typology, is of course not necessarily exhaustive. It may also not be generalisable. But judging from Karin Wahl-Jorgensen and Thomas Hanitzsch's account (2009:4-6), it seems that the Norwegian development has, more or less, followed the same path as has the rest of Europe - only often at later stages. European journalism studies are usually taken to have started as a normative and theoretical field in the nineteenth century; then an empirical and social science-inspired turn originated in the US and spread to other countries, before a cultural turn contributed to some extent to merging humanities and social sciences approaches. Most of the international developments in media studies have, however, taken place during the recent decades. This means that the 50 to 60 year-old history of Norwegian journalism education - and its academisation - has taken place within a fairly compressed period of time, a time when both journalism studies and media studies as such also came of age internationally.

The material on which this article is based consists of (a) documents preserved in the Norwegian J-schools' files and other relevant archives such as national archives, university archives, and press organisation archives; (b) research, textbooks, compendiums and other teaching aids from the 1970s onwards; (c) interviews; (d) press reports; and (e) other literature.

\section{Academisation from above or within?}

The first distinction I will make is the general one between academisation from above and academisation from within. This dichotomy serves to illustrate that academisation is to a large extent a question of where in the institutional structure the process takes place. There is a huge difference between, say, introducing more theories into the classroom and the decision on the part of authorities that an institution should be considered a college or university instead of a vocational school. 


\section{Academisation from above}

When it comes to higher education, the forces 'above' are most likely to be the authorities, but it could also be powerful organisations. The distinction between authorities and organisations is subsequently the first I will make.

\section{1) Academisation as a result of political decisions}

In Norway, a state-run journalism education was established by parliamentary decision in 1965. The University of Oslo took part in the planning, but before a formal affiliation was established it was decided that the new school should be run as an independent institution (Ottosen 1997; Volden 1982).

Around 1970 the school however became a building block on a new Norwegian polytechnic level, that soon expanded considerably in order to meet the general demand from the voluminous cohorts of post-war youth wanting to study above high-school level (Ottosen 1997; Volden 1982). The polytechnics' academic profile grew accordingly. By 1979, the J-school staff were formally recognised as scholars, not only as teachers, and were given access to the title of associate professor if qualified (it took another two decades to breed professors of journalism in Norway) (Fonn 2015). ${ }^{2}$

In the decades to follow, new legislation continued to bring professional education outside the university structure, and the universities, closer to each other all over the country. This process at national level strongly affected Norwegian journalism studies. But it was also an international trend - for example, in the UK, the formal distinction between universities and polytechnics was repealed in 1992 (Messel and Smeby 2017). The point of no return across the whole of Europe was the signing of the Bologna Declaration in 1999 which led to corresponding legislation in EU and EEA countries, including a harmonising of the degree structures. 
The Norwegian press organisations had from the start played a significant role by setting up an independent press-run tenmonth course in journalism, the Journalist Academy, from 1951. When the state-run J-school opened in 1965, press organisations had both initiated the plans and pulled many strings during the process. The involving of the university also shows that the organisations already in the 1960s were aware of the importance of an academic basis as part of the professionalisation of a trade (Fonn 2015; Lindholm 2014; Ottosen 2004 and 1997).

On the other hand, there were at the time porous borders between the press organisations and government offices (Wale 1972), and the press organisations may have believed that they would retain more influence over the education than they did in reality. In her history of the Swedish J-school Gardeström (2011:210) concludes that the Swedish press lost control of the education as soon as the authorities took over. In Norway, representatives of the press continued to be invited to sit on J-school committees. In the decades to come there were repeated conflicts between the school and the press organisations over the contents of the education, but also a lot of cooperation (Fonn 2015). The press never regained the power they had when the institution was established, but it is important to note that, for example, the Norwegian Journalists' Association was the first - as early as in 1989, well over a decade before it was finally established - to propose that a Master's degree in journalism be set up (Fonn 2015; Norsk Journalistlag, NJ/ Norsk Redaktørforening, NR 1993).

\section{Academising from within}

As we have seen, the decision to establish a tertiary state journalism education in Norway can first be said to have been a joint decision of the authorities and the press, and then the state took over.

A different kind of academisation takes place from within. In 1972, the British professor of philosophy Tyrell Burgess, who was also a recognised educational practitioner and journalist, coined 
the term 'academic drift' to describe a situation when the teaching staff take measures to make their education as close as possible to that in a university (based on Tight 2015:87). This does not imply of course that the teaching staff have full autonomy, as academisation from within will normally always supplement academisation from above.

There are, however, many elements that can make an educational programme resemble that of the universities. Let us have a look at the different ways journalism has historically been academised from within in Norway.

\section{3) Academisation surrounding journalism}

The first approach was most common in the decades after the war, at the press-run Journalist Academy and during the first years of the state-run journalism school. At the Academy, established in 1951, the academic elements were represented by lectures given by experts in various fields, in particular university professors in existing university disciplines - such as political science, economics or Norwegian literature. These disciplines represented knowledge that the future journalist was expected to need but which was not integrated with journalism. We could call this academisation surrounding journalism.

In fact, Carl Just, the principal of the Journalist Academy during all its 14 years of existence, and also the author of almost all Norwegian teaching aids in journalism that existed during the first decades after the war, opposed any further 'academisation'. He was very positive towards, and even proud of, the Academy's close relationship with the university. But on the other hand, he was of the opinion that journalism should not be considered an academic subject or be transformed into one (Just 1955). In many ways, Carl Just could be seen as belonging to the old socalled normative tradition. Almost all journalism educations can be said to be normative in one way or another, but 'normative' in this context in particular refers to proximity to the institution of the press. There was, for example, still a strong belief in journalism's edifying powers as well as its ability to reflect the world 'as it was'. As early as in Just's writings from the first post-war decades, there is however a visible tension between a belief in the news 
mirroring reality and the need to teach students how to avoid words and phrases which in reality had an underlying ideological meaning (Bastiansen 2005:314-16; Fonn 2015:25-27).

When the state journalism school was first established, its study programmes and general philosophy were, more or less, a copy of this system. It is important to note that at this stage, there was not necessarily any real difference between how university subjects and other kinds of 'external' knowledge were treated. Lectures on political science by university professors, or speeches about Norway's foreign diplomacy given by diplomats or on agricultural policy given by bureaucrats, were all regarded as necessary background knowledge for the up-and-coming journalist (for example, Norsk Journalistskole 1966), but in a way that primarily surrounded journalism teaching, rather than being an integrated part.

\section{4) The integrated academisation of journalism teaching}

The next step is when knowledge from other disciplines starts to be applied directly to the teaching of journalism. We could call this the integrated academisation of journalism teaching. From the new journalism school's institutional archive and reports in the trade magazine Journalisten we know that its first rector, Jon Dørsjø, took an early interest in the increasing awareness of the role language played in creating 'reality' (Norsk Journalistskole, 1966 and 1969; Journalisten 21965 and 6 1968; Dørsjø 1970). His approach seemed to include elements of what we know today as discourse analysis as well as constructivism.

Dørsjø's writings contained an element of media criticism that was not very widespread in the mid-1960s, but which soon became more common. With a growing youth culture, often tied to student revolts at the universities from 1968 onwards, criticism of the power elites proliferated. Not only the universities but also the press itself belonged to these power elites, and many journalism schools were influenced by the generally critical atmosphere of the era. The school could still be characterised as pre-academised, but its media criticism was academically inspired. This spurred considerable conflicts between the school and the press (Andenæs 2006:109-114; Ottosen 1996:363-369). Prominent peo- 
ple of the press perceived attempts of academisation and radicalisation to be one and the same thing (Fonn 2015:74-77; 180 ff.). According to Gardeström (2011:238 ff.), Dørsjø’s colleague and rector at the Stockholm School of Journalism, Lars Furhoff, was also an early proponent of such views - and subject to the same reactions in the press.

What we know of Dørsjø is largely based on strategic plans and articles. As an administrator, Dørsjø was less involved in teaching than the rest of the staff, so I have not been able to find any documentation relating directly to his teaching. The first attempts to integrate academic insights with the teaching of journalism in the classroom, and of which documentation exists, however also contained a linguistic approach. In the early 1970s one teacher (the later acclaimed author Karsten Alnæs) started to apply insights from linguistics, sociolinguistics and psycholinguistics directly to journalistic texts in his lessons. His teaching was documented in two reports, and later in the school's first published textbook (Alnæs 1971a, 1971b and 1973).

The aim of Alnæs's work was to make the students more aware of how they used language - its accessibility for large groups, any hidden argumentation in journalistic texts, and so on, and he used news texts actively in the classroom. In hindsight, it is also obvious that his book and reports included the recipe for conducting linguistic analyses - that is, research methodology.

In other words, this can be seen as an important turning point, where academic knowledge starts to be integrated with the teaching of journalism in Norway, at least judging from the existing documentation. This integration can subsequently be seen as a first step in the development of academic journalism.

It is, however, important to note that Alnæs, like Carl Just from the former generation of journalism educators, was also against any attempts to 'academise' the school. He even made a point of not wanting to see his own work as 'academisation', but as a necessary tool for practising journalists who wanted their texts to be as precise and available as possible (Alnæs, interview 2015; Ottosen 1996:368-369).

In the following years, teachers continued to develop these tools, and in due course they also came to be called academisation. From 1976, Alnæs's successor, Thore Roksvold, started 
building the school's language education on a clearly academic basis (Roksvold, interview 2015). An academic understanding of media texts became a cornerstone of classroom education, along with the more practical journalistic language training.

The same thing happened at the intersection between journalism and other academic subjects: insights and methods from academic history were integrated with the teaching of source criticism/verification (Egil Fossum, interview 2015). Insights from law and philosophy were integrated with the teaching of press ethics (Odd Raaum, interviews 2014 and 2015). In the archives we can also find traces of other attempts to integrate academic insights into teaching - for example, the use of social psychology in interviewing techniques (Norsk Journalistskole 1971).

\section{5) Journalism research through other disciplines}

Established academic subjects have, naturally, also been applied to journalism as research. So far, we have discussed the first identifiable academisation of the teaching of journalism. But, simultaneously with the development of journalism education in Norway, researchers in existing academic disciplines took an increasing interest in the workings of the press and other mass media.

The first major body of research that was relevant to Norwegian journalism was press research. At the end of the 1950s, press research was already an established separate field at the University of Oslo (Slaatta 2010; Ottosen 1997). Its establishment originated in the same context as the failed attempt to include journalism studies at the university.

Press research is not necessarily the same thing as journalism research. Yet press studies could easily be - and often are - included in journalism studies, and have been an important part of the development of journalism research. One important reason why it is today possible to distinguish between the two, however, is that historically they belonged to distinctly different institutions.

Initially, press studies followed an inherently social science approach (most notably based on political science or sociology), and was for years mainly conducted in the Faculty of Social Sci- 
ences at the University of Oslo and the independent (but with close ties to the University of Oslo) Institute of Social Research (Slaatta 2010). It centred primarily around media structure, media policy and questions about the public's reception of political communication through the press. Zelizer (2009:37) describes the political science approach, still a distinct field of research, as assuming an interdependence between politics and journalism, and with a vested interest in the political world.

As opposed to the US, where news writing was first taught in English departments before moving into journalism shools (Zelizer 2009:33), the Norwegian humanities departments came to this field relatively late. Among the few exceptions were the later professor of Nordic languages Finn Erik Vinje, who wrote the book Moderne norsk avisspråk (Modern Norwegian Newspaper Language) as early as in 1970, and the historian Hans Fredrik Dahl who attempted to merge history, sociology and communications theory in his book Massekommunikasjon from 1973. Both Alnæs and his successor Thore Roksvold were linguists, but they largely had to seek inspiration from Swedish and Danish philologists in their attempts to apply knowledge from linguistics to journalism (interviews Alnæs and Roksvold, 2015).

In the 1980s, the broader field of media research came of age along with a general expansion of media studies. This meant that the field was coming to embrace many more types of media than the press alone (including broadcast journalism) - it also entailed the study of cinema films, computer games, and so on. More important for our purpose was that the old 'monopoly' of the social scientists over press studies disintegrated. The early press research was not only based in the social sciences, but also made frequent use of quantitative methods. Now, humanists started to crowd the field, and media issues became subject to more use of qualitative methods. At the same time, a general constructivist turn in the social sciences contributed to further use of humanistic and/or qualitative methods and insights - this period is often referred to as the 'cultural turn' in social science. During the 1980s and 1990s, media studies developed to embrace both humanities and social sciences. Approaches from business studies or technology disciplines have also exerted influence on journalism studies, but this influence has, with a few exceptions, 
been most pronounced after the turn of the century, and is subsequently beyond the scope of this article.

\section{6) Institutionalised journalism studies}

In this atmosphere, publications that can be aptly described as journalism studies started to emerge as the first signs of an institutionalisation of journalism studies in Norway. A quarter of a century on, journalism was described as having 'matured to become a field of its own' on an international basis, with several journals and its own body of theories and literature (Wahl-Jorgensen and Hanitzsh 2009:4). According to Morlandstø (2012), this institutionalisation reached a critical mass in Scandinavia from the mid-1990s.

The first Norwegian contributions to this institutionalisation can be traced back to the late 1970s, and in particular from the early 1980s, when publications from the staff at the J-school started to emerge. Some developed in dialogue with the emerging press and media studies in other Norwegian institutions, some developed primarily as teaching tools. Some were plainly textbooks but with a value as journalistic $R \& D$; some had an intrinsic value as research, regardless of their practical use.

The 1980s and 1990s were characterised by a number of initiatives and debates about how Scandinavian journalism could develop as a research field of its own (Morlandstø 2012). The existing body of media research in Scandinavian countries was subject to two types of criticism, to an extent interrelated. The first criticism was that too little was about journalism, about its contents and conditions, or about the journalists. The other criticism was about the use of methods. Both scholars and representatives of the press started to advocate for research on journalism at this time, and they also pressed for more use of humanistic approaches and/or qualitative methods (see for example Dørsjø 1983; Hvitfeldt 1983 and Solstad cited in Nag 1996:121) - in line with the changes that were about to influence media studies as such.

When Lisbeth Morlandstø did her comprehensive study of Scandinavian journalism research up until 2009 (Morlandstø 2012), she built on these discussions from the 1980s and 1990s, 
and other later attempts to clarify what lies at the core of journalism studies as opposed to other media studies. One of the distinctions she found fruitful was Kent Asp's claim that 'genuine' journalism studies had to revolve around journalism as a product, as a working process, or as a social phenomenon (Asp 1992:68). Asp's definition excluded mere reception studies, and this also guided the demarcations in Morlandstø's work.

It was not a necessary requirement for the institutionalisation of journalism studies that the studies took place at the journalism schools themselves. But actors involved in both teaching and media research at the time stressed that if 'genuine' journalism research was to be done, it had to be done by journalist educators (Fonn 2015:125). The institutional changes that have taken place later, with time, blurred this distinction.

The Norwegian teachers who gave their first contributions to the institutionalisation of the field started examining journalistic texts in order to disclose their hidden patterns and get a better grip of what messages journalism actually conveyed. They applied existing insights from gender research or development studies to the journalistic profession, or collected concepts from academic history to improve students' understanding of source criticism. On the whole, the journalism research that developed from the late 1970s and 1980s onwards took a strong interest in the in-depth study of the contents of journalism, often using linguistic analysis and studying journalistic genres; or it could revolve around the journalist's role (including its historical development), and working processes. In Fonn (2015) I offer an overview of some of the most pivotal Norwegian journalism studies publications from the 1970s through to the 1990s.

At the stage where Norwegian journalism literature started to develop there was already a certain body of English language media literature. Judging from Zelizer's (2009) account of research on the media in the broader sense from the 1950s onwards, it is, however, doubtful that they would all meet the requirements set up by those Scandinavians who tried to institutionalise journalism studies. In Norway, the influence that these foreign works exerted was also, at best, varied, and it is difficult to trace because direct references to these works are scarce. According to Ottosen 
(2014), the main influence from other works of media and journalism came from other Nordic countries.

\section{7) Reflective journalism studies}

At the beginning of this article, I referred to the opinion that the study of journalism with time has been transformed from an originally normative study. This is, in a way, correct, given that the field has been strongly academised during the last century. But on the other hand, it is also correct to say that most journalism education has been, and still is, normative. Josephi (2009:42) describes journalism education as normally an attempt to 'improv[e] the quality of journalism by improving the quality of journalists'.

Closer scrutiny may reveal that a considerable amount of 'modern' journalism research also contains normative elements, at least through the choice of topics, research questions and so on. The natural question to ask following any such assumption is then: whose norms affect the study of journalism?

As early as in 1941, Paul Lazarsfeld made a useful distinction for communication studies which is still relevant, and definitely also relevant for journalism studies: the critical vs. the administrative approach. This is an aspect of the academisation of journalism that does not distinguish it from other media studies, but which may distinguish journalism programmes from each other - although they are all taught within the framework of academic institutions.

Whereas an administrative approach can be described as empirical research available for anyone with the means to pay for it, a critical approach is more theory-driven and more characterised by a wish to scrutinise the 'general role of our media of communication in the present social system' (Lasarzfeld 1941:9).

Especially after the rise of a critical culture from the 1960s onwards, a certain measure of self-reflection came to be accentuated as an important aspect of the humanities and social sciences (Lasarzfeld himself points to the influence of Max Horkheimer). We have also seen that academically inspired attempts at media criticism in the pre-academised Norwegian journalism education spurred intense conflicts with the industry, and that the 
same happened in Sweden. Such a reflective attitude is probably also an important reason for similar conflicts, in other countries and in other periods, between the industry and the academy. It may be at the core of discussions about whether the educational institutions should primarily serve an - often commercial - media industry, or put more weight on producing journalists who give the public the best possible information for democratic participation. In this schism we can detect both different and conflicting norms, and the inherent connection between theory and practice in professional educations.

Are reflective journalism studies a sub-category of journalism studies, or a category in its own right? It is both, but deserves to be treated as a category in its own right in this typology because of its strong scholarly position.

In a broad and diverse media studies landscape, both in the Nordic countries and elsewhere, it is possible to find institutions with an administrative approach as both research and education are concerned. But most journalism scholars today still adhere to the view that an academic approach to journalism could not be synonymous with merely reiterating the common truths of the trade or "help" the existing industry - it has to contain some kind of reflectivity about journalism as practice and its role in society. The president of Columbia University, Lee Bollinger, has, for example, stated that 'a great journalism school within a great university should always stand at a certain distance from the profession itself' (cited in Josephi 2009:50). According to Bollinger, reflective learning should always be an ideal in an academic institution - a point shared by most scholars today, according to Josephi. Bollinger claims that journalism scholars should be journalism's 'loyal critics'. Whether the current media crisis will make the better part of journalism scholars more loyal than critical remains open.

\section{8) Academised practice}

The mere notion of academisation is a difficult one in such a theoretical-practical subject as journalism. Many of the 'academisations' discussed above have affected both education and research. The last kind of academisation I will discuss in this arti- 
cle, is again a question of academised education. It refers to the introduction of academic methods directly into practice. Most journalism programmes contain practical training in some kind of in-house publications or broadcasting. This differs from the kind of classroom teaching and exercises like the first attempts to integrate journalism with linguistics described above. It is more like the classroom transferred to the newsroom: it is learning by doing. But the really important thing about the next example is that it also involves doing academics.

In both Sweden and Norway, some teachers took special care early on to develop practical tools inspired by academic methods and knowledge. The best-known of these people was Sweden's Furhoff, who already in the 1960s rejected the idea that journalists should be subject to endless lectures or textbooks about established university subjects. His idea was to integrate history, economics and sociology with journalistic practice - in the sense, for example, that reading economics was supplemented by, or even replaced by, relevant project work (Gardeström 2011:198). He would for example make students examine the lack of housing in Stockholm as a way of learning about economics.

In this way, insights from the social sciences were introduced directly into practical work. The same thing happened in Norway but, judging from the available documentation, at a later stage.

In 1977, the teacher Audun Bakke published a textbook which in fact served as a strong argument for using social scientific methods in practical journalism. On several occasions, the students were allowed to virtually take over the newsrooms at local papers, an even more challenging task than 'classroom' publishing. The year before, in 1976, Bakke had led a group of students on exchange at a local newspaper. In order to find out how the local public reacted to a new local development plan, the students performed a survey under Bakke's supervision. At the time, the use of these methods in journalism was regarded as so new that Bakke devoted over 50 pages to the experiment in his textbook (Fonn 2015:113; Bakke 1977:226-282). ${ }^{3}$

At this point, Furhoff had been advocating such methods for a decade, and it had certainly also been discussed for some time in the English-speaking world. Bakke was among others inspired by the American journalist and journalism scholar Philip Meyer, 
who in 1973 had published the book Precision Journalism, a call for journalists to get acquainted with the 'new tools' of social science. This is subsequently also one of the examples where we know that English-language publications did influence Norwegian educators.

Both the Swedish housing example and the Norwegian survey example are interesting forms of practice because they show how porous the boundaries between doing journalism and doing 'academics' can be. From the same period, we also find some examples of short student theses of the same character. It is in fact difficult to determine from the texts whether the students are doing journalism or sociology - except for the fact that the projects are less advanced than would be the case in a sociological project, and that we know they are doing journalism. Programme plans also testify to how what was once called computer assisted research (CAR) - itself based on research developed in the academy - was introduced into the education from the 1980s (Fonn 2015:186), an early sign of the technological turn that characterises much journalism education today. These are all examples of what we today regard as inherent parts of doing journalism. But when we look in the rear view mirror, we will see that at the time of introduction, they represented a kind of academisation of journalism - albeit a kind that had little to do with journalism research as such, but with practice.

An examination of the academic influence in the newsroom is beyond the scope of this article, but it is obvious that, for example, social science methods and tools are used every day. The application of more or less scientific methods in practical journalism is, in fact, often synonymous with investigative journalism. It does not have to be so - some of the finest pieces of investigative journalism throughout history have been literary works, and the main methods applied were human empathy, curiosity and great command of language. But it is also a fact that considerable present-day investigative journalism would not have been possible without knowledge of statistics, political science, economics, law, technology and so on, and the research tools they offer. Furthermore, it is a fact that much present-day noninvestigative journalism would be unthinkable without some 
degree of 'academisation' - journalists apply academic knowledge when interviewing, planning, writing op-eds and editorials. Among all these academic influences, it is likely that the body of knowledge built up over the years through journalism studies is influencing practitioners, regardless of their educational background - which could be anything from secondary education to journalism schools or an academic degree in social sciences or humanities.

The academisation of practice is of particular interest for the conflicts around the academising of journalism. As Josephi (2009:49) points out, the industry's argument is not necessarily against tertiary education as such, but against the disciplines of journalism or communication studies. This indicates that managers and editors often value the things that academic knowledge can add to journalistic practice, but that the more modern university subjects are met with more scepticism.

Josephi's claim is an interesting parallel to other former vocational educations. As the studies of the academisation of formerly vocational courses have come of age, it has become clear that this discussion is in no way confined to journalism. Ever since the considerable increase of young people in higher education from the 1960s, the upgrading of vocational schools and programmes to higher education has been a global trend (Smeby and Sutphen 2015). The same questions and concerns common to journalism have subsequently been raised in vocations such as teacher training, social work and nursing. Messel and Smeby (2017:51) refer to a study on nursing education in Norway in which fundamental problems such as those of history, philosophy and scientific theory were regarded as academisation whereas increased focus on natural sciences and medicine, for example, were regarded as a way of strengthening the functionality of the nurses. It seems quite likely that the same way of regarding different kinds of academic influence applies to journalism, and that the conflict goes deeper than a simple discord between 'theory' and 'practice'. 


\section{Concluding remarks}

This article is an attempt to clarify what we talk about when we discuss the academisation of journalism. Basing my argument on a historical study of the academisation of journalism in Norway, I have tried to develop a typology of altogether eight different ways that the structure or methods and knowledge of the academy have been introduced into journalism education after the apprenticeship system was replaced by college programmes from the mid- $20^{\text {th }}$ century on.

The different influences range from the so-called academisation from 'above' (mainly a question of structure) to different kinds of academisation from 'within' (mainly a question of content). I have identified two sources of academisation from above, resulting (1) from political decisions; or (2) from influence from press organisations. Furthermore, I have identified six types of academisation from within, which I have called: (3) academisation surrounding journalism; (4) the integrated academisation of journalism teaching; (5) journalism research through other disciplines; (6) institutionalised journalism studies; (7) reflective journalism studies; and (8) academised practice.

One important question that has engaged scholars of education for a long time is whether there is any real opposition between 'theory' and 'practice' in so-called professional education programmes (Messel and Smeby 2017). This is important to bear in mind whenever debaters seem to assume that there is limited space, and that introducing theories will somehow displace practical skills - or the other way around. I have argued that academisation is a far more complex process which, in the long run, has affected research, teaching and practising journalism. It is quite obvious that the joint decision of the politicians and the press associations to develop journalism as an academic subject, the so-called 'academisation from above', has played an important part. In addition, it is important to be aware of the complexity with which journalism has been academised from within. 


\section{NOTES}

1 One example is this 2015 debate article from representatives of the Norwegian press organisations: https://khrono.no/debatt/journalistutdanningene-ma-rustes-opp [Accessed 21 July 2017].

2 Sweden got its first journalism professor around 1990.

3 I owe my awareness of this example to my colleague at Oslo Metropolitan University, Magne Lindholm.

\section{REFERENCES:}

Andenæs, Ivar (2006). Ord og gjerning: Thorbjørn Wale, kriger og brobygger. Kristiansand: IJ-forlaget.

Alnæs, Karsten (1973). Språk og massemedier. Oslo: Cappelen.

Alnæs, Karsten (1971a). Om språklig tilgjengelighet. Oslo: Norsk Journalistskole.

Alnæs, Karsten (1971b). Roller og mønstre i massemedia. Oslo: Norsk Journalistskole.

Asp, Kent (1992). 'Journalistik som forskningsområde', pp. 59-79 in Ulla Carlsson and Anders Lindblad (Eds.) Forskning om journalistik, medier \& kommunikation. Ämnesområdet idag och i framtiden. Göteborg: Nordicom.

Bakke, Aaudun (1977). Analytisk journalistikk. Fredrikstad: Institutt for journalistikk.

Bastiansen, Henrik G. (2005). 'Referenten må alltid være på vakt. Carl Just og norsk journalistutdanning 1943-1965'. Norsk medietidsskrift, vol. 12 , no. 5 , pp. 309-324.

Dørsjø, Jon (1983). 'Om nødvendigheten av å etablere en journalistikkforskning', pp. 131-139. Pressens Årbog no. 1.

Dørsjø, Jon (1970, unpublished). Journalistutdanningen i dag og $i$ morgen. Bakgrunn og behov. Oslo: Norsk Journalistskole.

Evetts, Julia (2003). 'The sociological analysis of professionalism. Occupational change in the modern world'. International Sociology, vol. 18, no. 2, pp. 395-415.

Fonn, Birgitte Kjos (2015). 50 år med journalistutdanning. Om akademiseringen av et yrkesfag. Oslo: Cappelen Damm Akademisk.

Gardeström, Elin (2011). Att fostra journalister. Journalistutbildningens formering i Sverige 1944-1970. Gothenburg: Daidalos.

Hovden, Jan Fredrik; Gunnar Nygren \& Henrika Zilliacus-Tikkanen (2016). 'Introduction', in Hovden, Jan Fredrik; Gunnar Nygren \& Henrika Zilliacus-Tikkanen (Eds). Becoming a Journalist. Journalism Edu- 
cation in the Nordic Countries. Gothenburg: Nordicom.

Hovden, Jan Fredrik; Gunnar Nygren \& Henrika Zilliacus-Tikkanen (Eds.) (2016). Becoming a Journalist. Journalism Education in the Nordic Countries. Gothenburg: Nordicom.

Hvitfelt, Håkan (1983). 'Massekommunikationsforskning och journalistikforskning', pp. 107-118, Pressens Aarbog no. 2.

Josephi, Beate (2009). 'Journalism education', pp. 42-56 in Wahl-Jørgensen, K. \& T. Hanitzsch (Eds). Handbook of Journalism Studies. New York and London: Routledge.

Just, Carl (1955). 'Norsk journalistutdannelse'. Samtiden, vol. 66, no. 9, pp. 589-597.

Kyvik, Stein (2009). The Dynamic of Change in Higher Education. Expansion and Contraction in an Organisational Field. Dordrecht: Springer.

Lazarsfeld, Paul (1941). 'Remarks on administrative and critical communications research', Studies in Philosophy and Social Science, vol. 9, pp. 2-16.

Lindholm, Magne (2014). 'Journalistene', pp. 243-276 in Rune Slagstad \& Jan Messel (Eds.), Profesjonshistorier. Oslo: Pax.

McClelland, Charles E. (1990). 'Escape from Freedom? Reflections on German Professionalization 1870-1933', pp. 97-113 in R. Torstendahl \& M. Burrage (Eds.), The Formation of Professions: Knowledge, State and Strategy. London: Sage.

Messel, Jan and Jens-Christian Smeby (2017). 'Akademisering av høyskoleutdanningene?', pp. 44-55 in Sølvi Mausethagen \& Jens-Christian Smeby (Eds.). Kvalifisering til profesjonell yrkesutøvelse. Oslo: Universitetsforlaget.

Morlandstø, Lisbeth (2012). 'Institusjonalisering og vekst. En studie av journalistikkforskningen i Skandinavia', Nordicom Information, vol. 34, no. 3-4, pp. 3-17.

Nag, Wenche (1996). Medieforskningens Hvem vet best. En studie av møtet mellom Akademia og Pressen. Report no. 28, Department of Media Science, University of Bergen.

Nordenstreng, Karle (2007). 'Discipline or field? Soul-searching in Communication Research'. Nordicom Review, vol. 28, Jubilee Issue, pp. 211-222.

Norsk Journalistlag/ Norsk redaktørforening (1993). Three-year journalist education. A report from an NJ/ NR committe. Autumn 1993.

Norsk Journalistskole. Annual Reports 1966, 1969, 1971.

Ottosen, Rune (2014). 'The significance of Nordicom and the NordMe- 
dia Conference to Nordic media and communications research. Nordicom Review and Nordicom Information Special Issue, vol. 35/ vol. 36 no. 2, pp. 25-28.

Ottosen, Rune (2004). I journalistikkens grenseland. Journalistrollen mellom marked og idealer. Kristiansand: IJ-forlaget.

Ottosen, Rune (1997). 'Akademisk, kommersiell eller distriktspolitisk? Journalistutdanningens jakt på identitet'. Norsk medietidsskrift, vol. 4, no. 1, pp. 84-108.

Ottosen, Rune (1996). Fra fjaerpenn til internett. Journalister i organisasjon og samfunn. Oslo: Aschehoug.

Slaatta, Tore (2010). 'Norsk medieforskning i sosiologiens første tiår'. Sosiologi i dag, vol. 40, no. 4, pp. 5-31.

Smeby, Jens-Christian and Molly Sutphen (2015). From Vocational to Professional Education. Educating for Social Welfare. New York: Routledge.

Tight, Malcolm (2015). 'Theory development and application in higher education research: the case of academic drift'. Journal of Educational Administration and History, Vol. 47, no. 1, pp. 84-99.

Volden, Knut (1982). Journalistutdanningen og høgskolereformen $i$ 70-åra. Master's thesis in Social Pedagogy. University of Oslo.

Wale, Thorbjørn (1972). Fjerde statsmakt eller den annen partimakt? Master's thesis in Political Science. University of Oslo.

Wahl-Jorgensen, Karin and Thomas Hanitsch (2009). 'Introduction: On why and how we should do journalism studies', pp. 3-16 in Wahl-Jorgensen, Karin and Thomas Hanitzsch (Eds.), Handbook of Journalism Studies. New York and London: Routledge.

Zelizer, Barbie (2009). 'Journalism and the academy', pp. 29-41 in WahlJørgensen, K. and T. Hanitzsch (Eds), Handbook of Journalism Studies. New York and London: Routledge.

\section{AUTHOR}

Birgitte Kjos Fonn

Associate Professor, Oslo Metropolitan University, Norway birgitte@oslomet.no 